\title{
Implementasi Algoritma C4.5 Untuk Klasifikasi Penjualan Barang di Swalayan Dutalia
}

\author{
Aprilianus Kristianus Lalo ${ }^{* 1}$, Patrisius Batarius ${ }^{2}$, Yovinia Carmeneja Hoar Siki ${ }^{3}$ \\ ${ }^{1,2,3}$ Program Studi Ilmu Komputer, Fakultas Teknik, Universitas Katolik Widya Mandira \\ Jl. San Juan No 1, Penfui Timur 85361, Kupang Tengah, Kupang - NTT, Telp. (0380) 833395 \\ Email: *1. rickylalo29@gmail.com, ${ }^{2}$ patrisbatarius@ unwira.ac.id, ${ }^{3}$ yoviniacarmeneja@gmail.com
}

\begin{abstract}
ABSTRAK
Semua perusahaan ritel, termasuk Swalayan Dutalia, dituntut untuk mengambil keputusan secara tepat dalam strategi pemasaran dengan melihat kondisi pasar. Namun, pihak swalayan kerap kali mengalami kesulitan dalam memprediksi angka penjualan produk, terlebih lagi pihak swalayan belum memiliki teknik khusus guna melakukan prediksi angka penjualan barang di masa depan. Hal ini menyebabkan pihak swalayan tidak mampu menentukan stok minimum barang yang dijual.

Oleh karena itu, penelitian ini dilakukan untuk merancang bangun sebuah sistem yang menerapkan algoritma C4.5 untuk mengolah data dalam jumlah besar untuk menemukan pola penjualan barang. Berdasarkan decision tree yang terbentuk, akan dilakukan prediksi terhadap kumpulan data penjualan barang baru. Sehingga, pihak Swalayan Dutalia dapat menentukan stok minimum barang. Atribut yang digunakan berjumlah enam buah, yaitu jenis barang, harga, jumlah jual, waktu jual, momen jual, dan status penjualan sebagai atribut target. Berdasarkan pengujian terhadap data training dan data hasil prediksi pada aplikasi RapidMiner Studio Version 9.7, akurasi perhitungan yang dihasilkan mencapai $100 \%$ sehingga sistem yang dirancang bangun dapat digunakan untuk memprediksi penjualan barang di masa depan.
\end{abstract}

Kata Kunci: Swalayan Dutalia, Algoritma C4.5, Decision Tree, Prediksi Penjualan

\begin{abstract}
All of retail companies, including Dutalia Supermarket, are required to take the right decision in marketing strategy by observing market condition. However, the supermarket often has a difficulty to predict numbers of product sale, even it doesn't have a special technique to predict the numbers of sale for the future. So, it causes the supermarket can't determine minimum number of supplies.

Because of that, this research is made to build a system that applying C4.5 algorithm to proccess a big data of products sale to see pattern of sale. Based on decision tree, a prediction of new collection of products sale data can be made. So, Dutalia Supermarket can determine minimum numbers of supplies. The research uses six atributes, they are kinds of product, price, total of products sale, time of sale, moment of sale, and sales status as the target atribute. Based on data training and prediction data test using RapidMiner Studio Version 9.7 application, the accuration of the calculation reaches $100 \%$, so it can be concluded that the established system can be used to predict products sale in the future.
\end{abstract}

Keywords: Dutalia Supermarket, C4.5 Algorithm, Decision Tree, Sale Prediction

\section{PENDAHULUAN}

Perkembangan persaingan di bidang bisnis disertai kemajuan di bidang teknologi informasi mengantarkan perusahaan-perusahaan ritel saat ini, termasuk di Indonesia, pada persaingan yang ketat dan lebih terbuka. Setiap perusahaan dituntut untuk mengambil keputusan secara tepat dalam strategi pemasaran dengan melihat kondisi pasar.

Pada perusahaan ritel, seperti pada Swalayan Dutalia, salah satu cara yang bisa dilakukan untuk mengetahui kondisi pasar adalah dengan mengamati data transaksi penjualan. Data transaksi penjualan disimpan dalam data warehouse swalayan. Namun, tumpukan data transaksi tersebut nyatanya belum dimanfaatkan secara efektif. Data yang begitu besar hanya dimanfaatkan sebagai bahan pembuatan laporan penjualan per bulan tanpa menggali informasi atau pengetahuan baru dari pola transaksi yang ada. 
Belum adanya cara mengolah informasi yang efektif dari kumpulan data penjualan di tengah angka penjualan produk yang fluktuatif banyak kali menjadi sumber masalah baru bagi pihak swalayan. Pihak swalayan kerap kali mengalami kesulitan dalam memprediksi angka penjualan produk, terlebih lagi pihak swalayan belum memiliki teknik khusus guna melakukan peramalan angka penjualan di masa depan. Hal ini mengakibatkan swalayan kesulitan menentukan stok minimum tiap barang secara efektif, sehingga yang terjadi adalah adanya penimbunan stok barang di gudang perusahaan ataupun habisnya stok barang yang paling diminati konsumen karena kebutuhan pasar tidak diimbangi persediaan barang.

Oleh sebab itu, Swalayan Dutalia membutuhkan suatu teknik otomatis di bidang teknologi informasi guna mengatasi masalah tersebut, yaitu data mining. Data mining adalah proses yang menggunakan teknik statistik, matematika, kecerdasan buatan, dan machine learning untuk mengekstraksi dan mengidentifikasi informasi yang bermanfaat dan pengetahuan yang terkait dari berbagai database besar. (Harahap, 2015)

Teknik klasifikasi dengan Algoritma C4.5 dalam Data Mining adalah salah satu metode yang dapat dimanfaatkan dalam kaitannya dengan prediksi angka penjualan produk atau barang. Algoritma C4.5 digunakan untuk menghasilkan model berupa decision tree (pohon keputusan) dimana pohon atau aturan yang terbentuk berguna dalam membaca prediksi, khususnya dalam kaitan dengan prediksi penjualan produk terlaris di Swalayan Dutalia.

Penggunaan algoritma $\mathrm{C} 4.5$ tentu harus dilengkapi dengan variabel-variabel atau atribut-atribut yang turut mengindikasikan sebuah produk dengan status penjualan laris atau tidak laris sehingga pihak swalayan dapat menyiapkan stok yang sesuai dengan kebutuhan pelanggan. Atribut-atribut yang dimaksudkan adalah jenis barang, jumlah penjualan, harga barang, waktu jual, momen penjualan (hari raya, hari biasa, hari libur), dan status penjualan (laris, tidak laris) sebagai atribut kelas (atribut target).

Berdasarkan uraian persoalan yang dihadapi oleh pihak Swalayan Dutalia, maka penting bagi peneliti untuk mengevaluasi data penjualan barang agar dapat menerapkan Algoritma C4.5 untuk klasifikasi produk sehingga pihak swalayan dapat memperoleh informasi berupa pola penjualan produk atau barang berdasarkan riwayat penjualan barang di masa lampau yang akan turut mendukung dalam pengambilan kebijakan perusahaan di masa yang akan datang.

\section{KLASIFIKASI}

Klasifikasi adalah proses menemukan kumpulan pola atau fungsi-fungsi yang mendeskripsikan dan memisahkan kelas data satu dengan lainnya agar dapat digunakan untuk memprediksi data yang belum memiliki kelas data tertentu.(Rosela, 2019)

\subsection{Algoritma C4.5}

Algoritma C4.5 merupakan salah satu teknik klasifikasi pada machine learning yang digunakan pada proses data mining dengan membentuk sebuah pohon keputusan (decision tree) yang direpresentasikan dalam bentuk aturan.(Pritalia, 2018)

Berikut adalah langkah-langkah perhitungan:

1. data dikelompokkan berdasarkan atribut beserta nilai di dalamnya;

2. menghitung jumlah data pada setiap nilai atribut yang ada;

3. mengklasifikasi data yang sudah dihitung menjadi dua kelompok berdasarkan terget tujuan, yaitu laris (L) dan tidak laris (TL);

4. menghitung entropy total dari 20 data penjualan barang;

5. menghitung entropy dari masing-masing nilai atribut;

6. menghitung gain dari tiap atribut;

7. menghitung gain ratio dari tiap atribut;

8. mencari atribut dengan gain ratio tertinggi untuk dijadikan root;

9. menentukan nilai atribut yang akan dijadikan cabang;

10. menentukan node selanjutnya dari atribut yang terpilih berdasarkan nilai gain ratio tertinggi.

\section{METODE PENELITIAN}

Dalam penelitian ini, metode yang diterapkan adalah metode rekayasa perangkat lunak model waterfall. Model Waterfall adalah suatu proses pengembangan perangkat lunak berurutan, dimana kemajuan dipandang sebagai arus yang terus mengalir ke bawah (seperti air terjun) melewati fase-fase perencanaan, pemodelan, implementasi (konstruksi), dan pengujian.(Tristianto, 2018) 
Tahap-tahap dalam model penelitian waterfall adalah sebagai berikut.

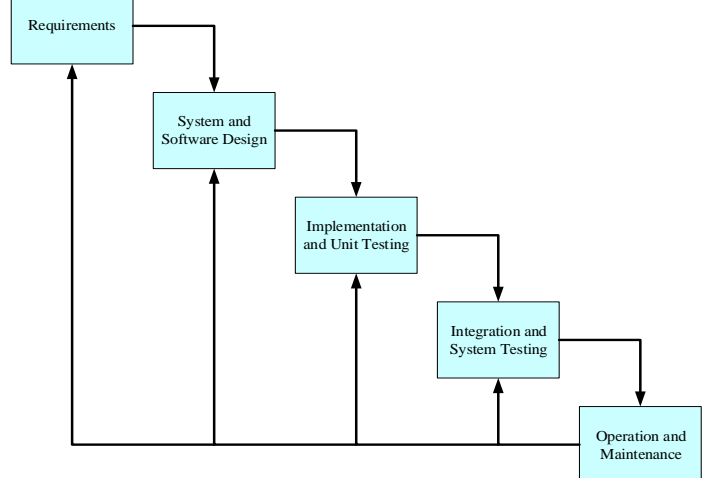

Gambar 1. Tahap-Tahap Metode Waterfall

Penelitian ini membutuhkan data atribut, data nilai atribut, data training, dan data prediksi seperti terlihat pada Tabel 1, Tabel 2 dan Tabel 3.

Tabel 1. Data Atribut dan Nilai Atribut

\begin{tabular}{|c|c|}
\hline Atribut & Nilai Atribut \\
\hline \multirow[t]{27}{*}{$\begin{array}{c}\text { Jenis } \\
\text { Barang }\end{array}$} & Beras Jeruk $20 \mathrm{~kg}$ \\
\hline & Bimoli 1 Ltr Rfl \\
\hline & Bimoli 2 Ltr Rfl \\
\hline & Mie Sedap Goreng \\
\hline & Gula Pasir Hasta 1 \\
\hline & Terigu $1 \mathrm{~kg}$ \\
\hline & Terigu $500 \mathrm{~g}$ \\
\hline & Kopi TB 450 \\
\hline & Teh Sari Wangi 25 \\
\hline & Mie Sedap Soto \\
\hline & Telur Ayam \\
\hline & Daia Bunga $850 \mathrm{~g}$ \\
\hline & Rinso An 900 g \\
\hline & Dancow Cokelat Forts \\
\hline & Dancow Cokelat $800 \mathrm{~g}$ \\
\hline & Garam C Kpl 250 \\
\hline & Bear Brand $189 \mathrm{ML}$ \\
\hline & $\begin{array}{l}\text { Mama Lemon Jrk Nps } \\
400 \mathrm{ml}\end{array}$ \\
\hline & Lifebuoy Lemonfresh \\
\hline & $\begin{array}{l}\text { SGM Ananda 400g 6-12 } \\
\text { bln }\end{array}$ \\
\hline & You C1000 Vit. Orange \\
\hline & Aqua $1500 \mathrm{ml} / \mathrm{fc}$ \\
\hline & Bir Bintang Btl 620 \\
\hline & Coca Cola Btl 1.5 Lt \\
\hline & Pulpy Orange 350 \\
\hline & Le Minerale Btl $600 \mathrm{ml}$ \\
\hline & $\begin{array}{c}\text { Mamy Poko Pant } \\
\text { Standar }\end{array}$ \\
\hline
\end{tabular}




\begin{tabular}{|c|c|}
\hline \multirow[t]{10}{*}{ Atribut } & Nilai Atribut \\
\hline & Nescafe Classic 10x2g \\
\hline & DCW $1+$ MD $1000 \mathrm{~g}$ \\
\hline & $\begin{array}{c}\text { Kecap Manis Sedap } 135 \\
\mathrm{ml}\end{array}$ \\
\hline & $\begin{array}{c}\text { Krisbee Fries Kentang } \\
\text { Grg } 75 \mathrm{~g}\end{array}$ \\
\hline & $\begin{array}{c}\text { Kopi Top White } 12 \times 21 \\
\mathrm{~g}\end{array}$ \\
\hline & Jas Jus 10 g Melon \\
\hline & $\begin{array}{c}\text { Morinaga Bmt Lacto } \\
400 \mathrm{~g}\end{array}$ \\
\hline & $\begin{array}{c}\text { Chilml } 2 \text { DHA } 200 \\
\text { Original }\end{array}$ \\
\hline & Chilml DHA $400 \mathrm{~g}$ \\
\hline \multirow[t]{2}{*}{ Harga } & $<100$ ribu \\
\hline & $>=100$ ribu \\
\hline \multirow{2}{*}{$\begin{array}{c}\text { Jumlah } \\
\text { Jual }\end{array}$} & $<=250$ \\
\hline & $>250$ \\
\hline \multirow[t]{12}{*}{$\begin{array}{l}\text { Waktu } \\
\text { Jual }\end{array}$} & Januari \\
\hline & Februari \\
\hline & Maret \\
\hline & April \\
\hline & Mei \\
\hline & Juni \\
\hline & Juli \\
\hline & Agustus \\
\hline & September \\
\hline & Oktober \\
\hline & November \\
\hline & Desember \\
\hline \multirow[t]{3}{*}{$\begin{array}{c}\text { Momen } \\
\text { Jual }\end{array}$} & Hari Raya \\
\hline & Hari Biasa \\
\hline & Hari Libur \\
\hline
\end{tabular}

Data atribut dan nilai atribut merupakan kriteria yang memengaruhi omzet penjualan barang. Data training dan data prediksi yang di-input harus mencakup atribut dan nilai atribut tersebut.

Tabel 2. Data Training

\begin{tabular}{|c|c|c|c|c|c|c|}
\hline NO. & Jenis Barang & Harga & $\begin{array}{c}\text { Jumlah } \\
\text { Jual }\end{array}$ & $\begin{array}{c}\text { Waktu } \\
\text { Jual }\end{array}$ & $\begin{array}{c}\text { Momen } \\
\text { Jual }\end{array}$ & Status \\
\hline 1 & Beras Jeruk 20 kg & $>=100$ ribu & $<=250$ & Januari & Hari Raya & Tidak Laris \\
\hline 2 & Bimoli 1 Liter Rfl & $<100 \mathrm{ribu}$ & $<=250$ & Januari & Hari Raya & Laris \\
\hline 3 & Bimoli 2 Liter Rfl & $<100 \mathrm{ribu}$ & $<=250$ & Januari & Hari Biasa & Tidak Laris \\
\hline 4 & Mie Sedap Goreng & $<100 \mathrm{ribu}$ & $>250$ & Januari & Hari Biasa & Laris \\
\hline 5 & Gula Pasir Hasta 1 & $<100 \mathrm{ribu}$ & $>250$ & Januari & Hari Raya & Laris \\
\hline
\end{tabular}




\begin{tabular}{|c|c|c|c|c|c|c|}
\hline NO. & Jenis Barang & Harga & $\begin{array}{c}\text { Jumlah } \\
\text { Jual }\end{array}$ & $\begin{array}{c}\text { Waktu } \\
\text { Jual }\end{array}$ & $\begin{array}{c}\text { Momen } \\
\text { Jual }\end{array}$ & Status \\
\hline 6 & Terigu $1 \mathrm{~kg}$ & $<100 \mathrm{ribu}$ & $<=250$ & Januari & Hari Raya & Tidak Laris \\
\hline 7 & Terigu $500 \mathrm{~g}$ & $<100 \mathrm{ribu}$ & $<=250$ & Januari & Hari Libur & Tidak Laris \\
\hline 8 & Kopi TB 450 & $<100 \mathrm{ribu}$ & $<=250$ & Januari & Hari Biasa & Laris \\
\hline 9 & Teh Sari Wangi 25 & $<100 \mathrm{ribu}$ & $>250$ & Januari & Hari Biasa & Laris \\
\hline 10 & Mie Sedap Soto & $<100 \mathrm{ribu}$ & $>250$ & Januari & Hari Biasa & Laris \\
\hline$\ldots .$. & & & & & \\
\hline 430 & Morinaga Bmt Lacto 400g & $<100 \mathrm{ribu}$ & $<=250$ & Desember & Hari Libur & Tidak Laris \\
\hline 431 & Chilml 2 DHA 200 & $<100 \mathrm{ribu}$ & $<=250$ & Desember & Hari Libur & Tidak Laris \\
\hline 432 & Chilginal & $<100 \mathrm{ribu}$ & $<=250$ & Desember & Hari Biasa & Tidak Laris \\
\hline
\end{tabular}

Data training digunakan dalam proses training untuk menemukan pola penjualan menggunakan Algoritma C4.5. Pola yang dihasilkan berupa pohon keputusan yang berisikan rules penjualan. Rules yang dihasilkan akan digunakan untuk melakukan prediksi status penjualan barang yang baru.

Tabel 3. Data Prediksi

\begin{tabular}{|c|c|c|c|c|c|}
\hline NO. & Jenis Barang & Harga & $\begin{array}{c}\text { Jumlah } \\
\text { Jual }\end{array}$ & $\begin{array}{c}\text { Waktu } \\
\text { Jual }\end{array}$ & Momen Jual \\
\hline 1 & Beras Jeruk $20 \mathrm{~kg}$ & $>=100$ ribu & $<=250$ & Januari & Hari Raya \\
\hline 2 & Bimoli 1 Liter Rfl & $<100$ ribu & $<=250$ & Januari & Hari Raya \\
\hline 3 & Bimoli 2 Liter Rfl & $<100$ ribu & $<=250$ & Januari & Hari Biasa \\
\hline 4 & Mie Sedap Goreng & $<100$ ribu & $>250$ & Februari & Hari Biasa \\
\hline 5 & Gula Pasir Hasta 1 & $<100$ ribu & $>250$ & Februari & Hari Biasa \\
\hline 6 & Terigu $1 \mathrm{~kg}$ & $<100$ ribu & $<=250$ & Februari & Hari Libur \\
\hline 7 & Terigu $500 \mathrm{~g}$ & $<100$ ribu & $<=250$ & Maret & Hari Raya \\
\hline 8 & Kopi TB 450 & $<100$ ribu & $<=250$ & Maret & Hari Libur \\
\hline 9 & Teh Sari Wangi 25 & $<100$ ribu & $>250$ & Maret & Hari Biasa \\
\hline 10 & Mie Sedap Soto & $<100$ ribu & $>250$ & April & Hari Biasa \\
\hline \multicolumn{6}{|l|}{$\ldots \ldots$} \\
\hline 40 & Coca Cola Btl 1.5 Lt & $<100$ ribu & $>250$ & Desember & Hari Raya \\
\hline 41 & Pulpy Orange 350 & $<100 \mathrm{ribu}$ & $>250$ & Desember & Hari Libur \\
\hline 42 & Le Minerale Btl $600 \mathrm{ml}$ & $<100$ ribu & $>250$ & Desember & Hari Libur \\
\hline 43 & Mamy Poko Pant Standar & $<100$ ribu & $<=250$ & Desember & Hari Biasa \\
\hline 44 & Nescafe Classic 10x2g & $<100$ ribu & $<=250$ & Desember & Hari Biasa \\
\hline 45 & DCW $1+$ MD $1000 \mathrm{~g}$ & $<100$ ribu & $<=250$ & Desember & Hari Libur \\
\hline 46 & Kecap Manis Sedap $135 \mathrm{ml}$ & $<100$ ribu & $<=250$ & Desember & Hari Biasa \\
\hline 47 & Krisbee Fries Kentang Grg $75 \mathrm{~g}$ & $<100$ ribu & $<=250$ & Desember & Hari Biasa \\
\hline 48 & Kopi Top White $12 \times 21 \mathrm{~g}$ & $<100$ ribu & $<=250$ & Desember & Hari Biasa \\
\hline 49 & Jas Jus $10 \mathrm{~g}$ Melon & $<100$ ribu & $<=250$ & Desember & Hari Biasa \\
\hline 50 & Morinaga Bmt Lacto 400g & $<100$ ribu & $<=250$ & Desember & Hari Libur \\
\hline
\end{tabular}

Data prediksi berisikan data barang beserta atribut yang memengaruhi omzet penjualannya. Data prediksi belum memiliki status penjualan, sehingga harus dilakukan prediksi untuk menentukan status penjualannya. 


\section{HASIL DAN PEMBAHASAN}

\subsection{Perhitungan Root Decision Tree Dari Data Training}

Pada perhitungan penentuan root (akar), data akan dikelompokkan berdasarkan atribut dan nilai atribut. Kemudian, setiap nilai atribut akan dicari nilai entropy-nya. Setelah diketahui nilai entropy, setiap atribut akan dicari nilai gain, split info, dan gain ratio.

Tabel 4. Perhitungan Penentuan Root

\begin{tabular}{|c|c|c|c|c|c|c|c|c|c|}
\hline $\begin{array}{l}\text { No } \\
\text { de }\end{array}$ & Atribut & Nilai Atribut & $\mathbf{S}$ & Laris & $\begin{array}{l}\text { Tidak } \\
\text { Laris }\end{array}$ & Entropy & Gain & $\begin{array}{l}\text { Split } \\
\text { Info }\end{array}$ & $\begin{array}{l}\text { Gain } \\
\text { Ratio }\end{array}$ \\
\hline \multirow[t]{32}{*}{0} & Total & & 432 & 246 & 186 & 0.986 & & & \\
\hline & \multirow{31}{*}{$\begin{array}{l}\text { Jenis } \\
\text { Barang }\end{array}$} & Beras Jeruk $20 \mathrm{~kg}$ & 12 & 11 & 1 & 0.414 & & & \\
\hline & & Bimoli 1 Ltr Rfl & 12 & 10 & 2 & 0.650 & & & \\
\hline & & Bimoli 2 Ltr Rfl & 12 & 2 & 10 & 0.650 & & & \\
\hline & & Mie Sedap Goreng & 12 & 10 & 2 & 0.650 & & & \\
\hline & & Gula Pasir Hasta 1 & 12 & 12 & 0 & 0 & & & \\
\hline & & Terigu $1 \mathrm{~kg}$ & 12 & 11 & 1 & 0.414 & & & \\
\hline & & Terigu $500 \mathrm{~g}$ & 12 & 7 & 5 & 0.980 & & & \\
\hline & & Kopi TB 450 & 12 & 12 & 0 & 0 & & & \\
\hline & & Teh Sari Wangi 25 & 12 & 12 & 0 & 0 & & & \\
\hline & & Mie Sedap Soto & 12 & 12 & 0 & 0 & & & \\
\hline & & Telur Ayam & 12 & 12 & 0 & 0 & & & \\
\hline & & Daia Bunga $850 \mathrm{~g}$ & 12 & 10 & 2 & 0.650 & & & \\
\hline & & Rinso An 900 g & 12 & 0 & 12 & 0 & & & \\
\hline & & Dancow Cokelat Forts & 12 & 11 & 1 & 0.414 & & & \\
\hline & & Dancow Cokelat $800 \mathrm{~g}$ & 12 & 0 & 12 & 0 & & & \\
\hline & & Garam C Kpl 250 & 12 & 12 & 0 & 0 & & & \\
\hline & & Bear Brand $189 \mathrm{ML}$ & 12 & 12 & 0 & 0 & & & \\
\hline & & $\begin{array}{l}\text { Mama Lemon Jrk Nps } \\
400 \mathrm{ml}\end{array}$ & 12 & 1 & 11 & 0.414 & & & \\
\hline & & Lifebuoy Lemonfresh & 12 & 12 & 0 & 0 & & & \\
\hline & & $\begin{array}{l}\text { SGM Ananda 400g 6- } \\
12 \mathrm{bln}\end{array}$ & 12 & 4 & 8 & 0.918 & & & \\
\hline & & $\begin{array}{c}\text { You C1000 Vit. } \\
\text { Orange } \\
\end{array}$ & 12 & 12 & 0 & 0 & & & \\
\hline & & Aqua $1500 \mathrm{ml} / \mathrm{fc}$ & 12 & 12 & 0 & 0 & & & \\
\hline & & Bir Bintang Btl 620 & 12 & 12 & 0 & 0 & & & \\
\hline & & Coca Cola Btl 1.5 Lt & 12 & 9 & 3 & 0.811 & & & \\
\hline & & Pulpy Orange 350 & 12 & 12 & 0 & 0 & & & \\
\hline & & $\begin{array}{l}\text { Le Minerale Btl } 600 \\
\text { ml }\end{array}$ & 12 & 12 & 0 & 0 & & & \\
\hline & & $\begin{array}{l}\text { Mamy Poko Pant } \\
\text { Standar }\end{array}$ & 12 & 2 & 10 & 0.650 & & & \\
\hline & & Nescafe Classic 10x2g & 12 & 0 & 12 & 0 & & & \\
\hline & & DCW $1+$ MD $1000 \mathrm{~g}$ & 12 & 0 & 12 & 0 & & & \\
\hline & & $\begin{array}{c}\text { Kecap Manis Sedap } \\
135 \mathrm{ml} \\
\end{array}$ & 12 & 4 & 8 & 0.918 & & & \\
\hline & & $\begin{array}{c}\text { Krisbee Fries Kentang } \\
\text { Grg } 75 \mathrm{~g}\end{array}$ & 12 & 5 & 7 & 0.980 & & & \\
\hline
\end{tabular}




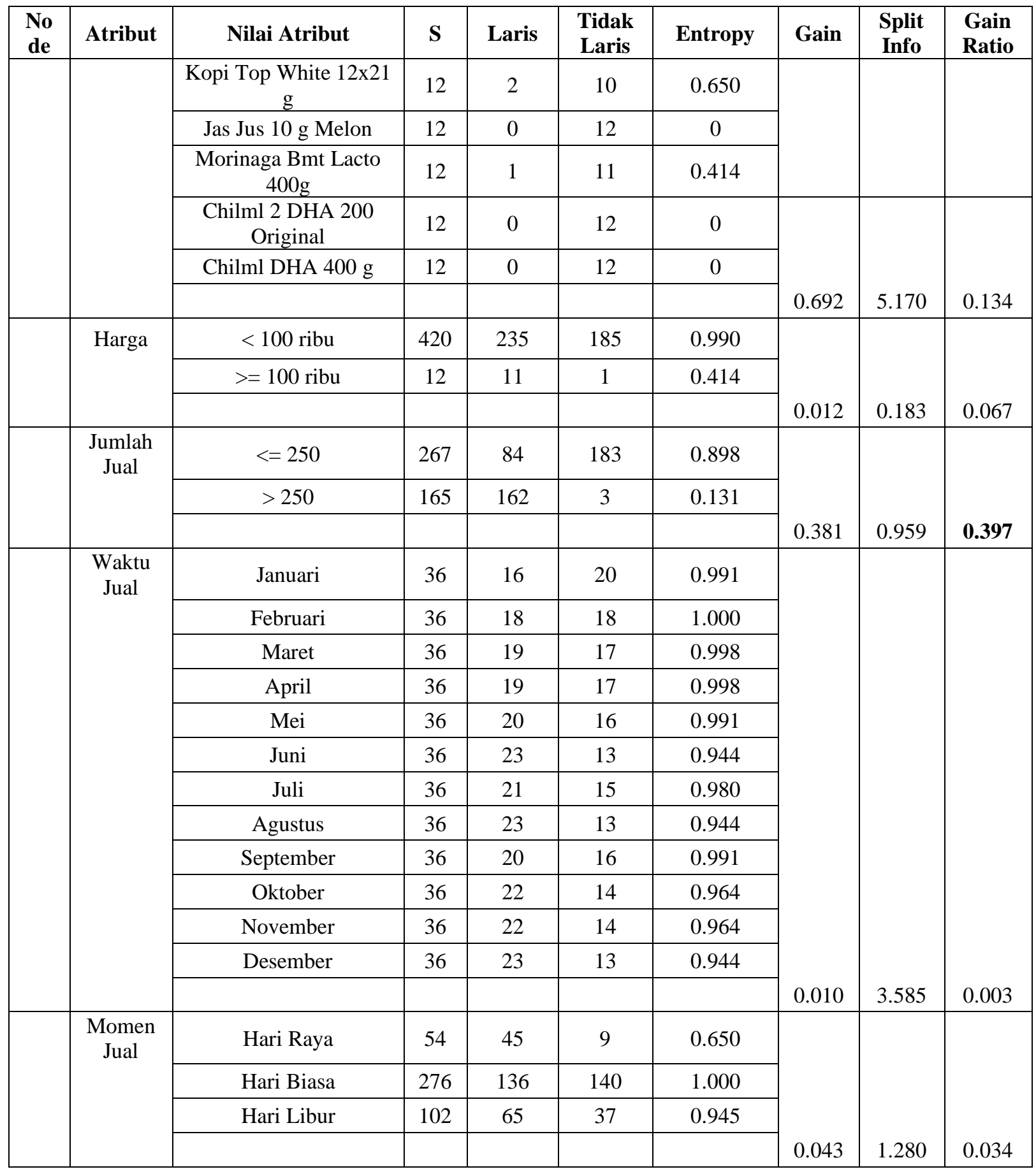

Perhitungan Entropy Total tabel penentuan ROOT adalah sebagai berikut.

Entropy $($ Total $)=\left(-\frac{246}{432} * \log _{2}\left(\frac{246}{432}\right)\right)+\left(-\frac{186}{432} * \log _{2}\left(\frac{186}{432}\right)\right)=0.986$

Perhitungan Entropy pada tiap nilai atribut dihitung dengan cara yang sama.

Entropy (Momen Jual, Hari Raya) $=\left(-\frac{45}{54} * \log _{2}\left(\frac{45}{54}\right)\right)+\left(-\frac{9}{54} * \log _{2}\left(\frac{9}{54}\right)\right)=0.65$

Lalu, perhitungan nilai Gain untuk atribut Momen Jual dan atribut lainnya dihitung dengan persamaan gain sebagai berikut.

Gain $($ Total, Momen Jual $)=0.986-\left(\frac{54}{432} * 0.65+\frac{276}{432} * 1+\frac{102}{432} * 0.945\right)=0.043$

Selanjutnya, perhitungan nilai Split Info dan Gain Ratio untuk atribut Momen Jual dan atribut lainnya dihitung dengan cara sebagai berikut.

SplitInfo $($ Momen Jual $)=-\left(\left(\frac{54}{432} * \log _{2}\left(\frac{54}{432}\right)+\left(\frac{276}{432} * \log _{2}\left(\frac{276}{432}\right)+\left(\frac{102}{432} * \log _{2}\left(\frac{102}{432}\right)\right)=1.28\right.\right.\right.$ 
Gain Ratio $($ Momen Jual $)=\frac{\operatorname{Gain}(S, A)}{\operatorname{SplitInfo(S,A)}}=\frac{0.043}{1.28}=0.034$

Berdasarkan hasil perhitungan pada tabel, atribut yang memiliki nilai Gain Ratio terbesar adalah Jumlah Jual, yaitu sebesar 0.397. Maka, Jumlah Jual menjadi node akar (root). Terdapat dua nilai atribut Jumlah Jual, yaitu $(<=250)$ dan ( $>250)$. Dua nilai atribut Jumlah Jual diklasifikasikan berdasarkan nilai Laris (L) dan Tidak Laris (TL). Apabila nilai $\mathrm{L}=0$ dan $\mathrm{TL}>0$, maka akan menghasilkan rule Tidak Laris (TL). Sebaliknya, apabila nilai $\mathrm{L}>0$ dan $\mathrm{TL}=0$, maka menghasilkan rule Laris. Berdasarkan tabel, niilai atribut $(<=250)$ dan $(>250)$ sama-sama memiliki nilai $\mathrm{L}>0$ dan $\mathrm{TL}>0$, maka perlu dihitung lagi untuk mencari Node selanjutnya.

Metode perhitungan untuk node selanjutnya sama dengan perhitungan menentukan node yang ada. Perbedaannya adalah atribut dengan nilai terbesar pada perhitungan sebelumnya tidak dihitung lagi. Atribut total diganti dengan total dari nilai atribut terbesar pada perhitungan sebelumnya.

\subsection{Decision Tree yang Terbentuk}

Berdasarkan perhitungan secara keseluruhan, maka dihasilkan sebuah pohon keputusan akhir yang merangkum semua atribut beserta nilai atributnya pada Gambar 2 dan Gambar 3 berikut.

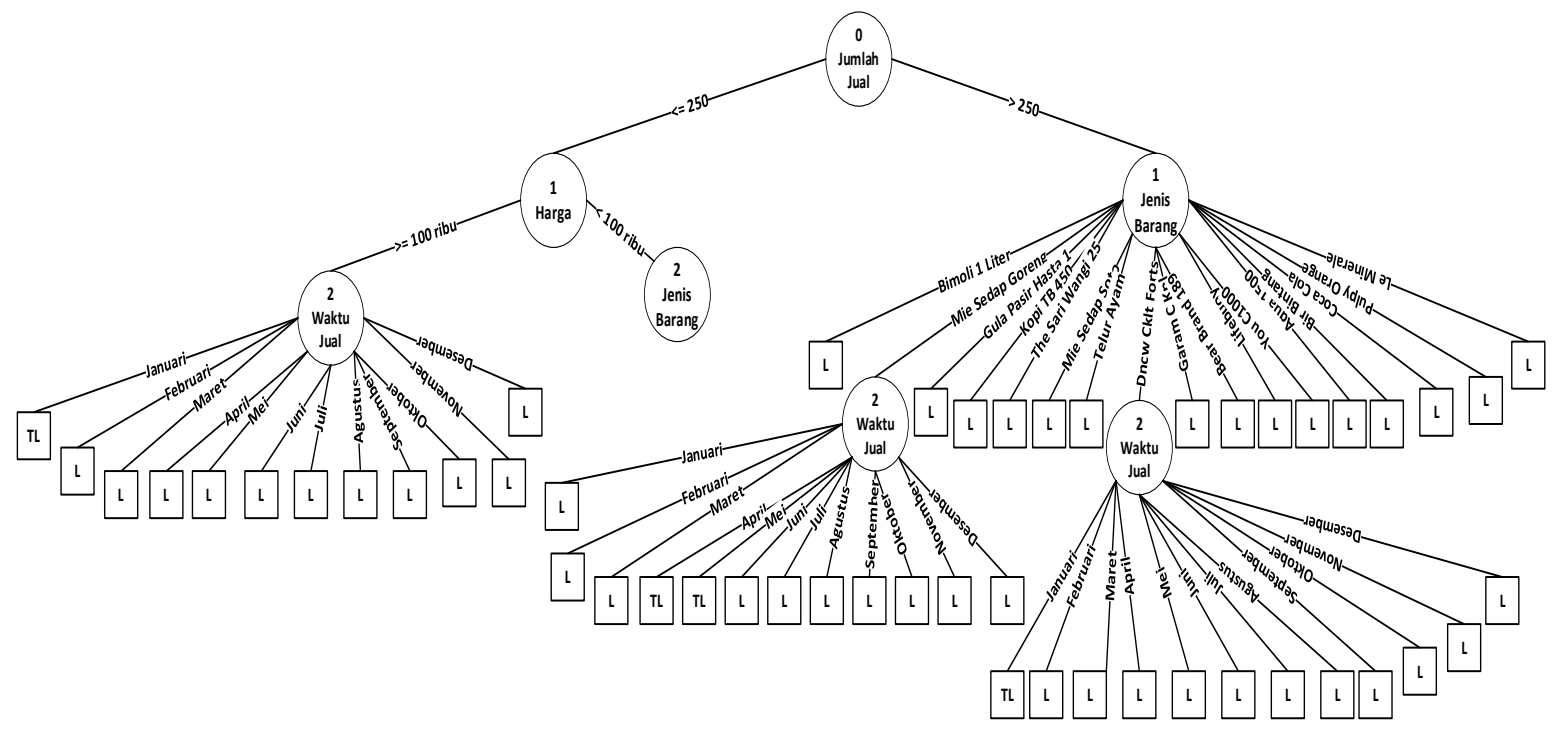

Gambar 2. Decision Tree yang Terbentuk

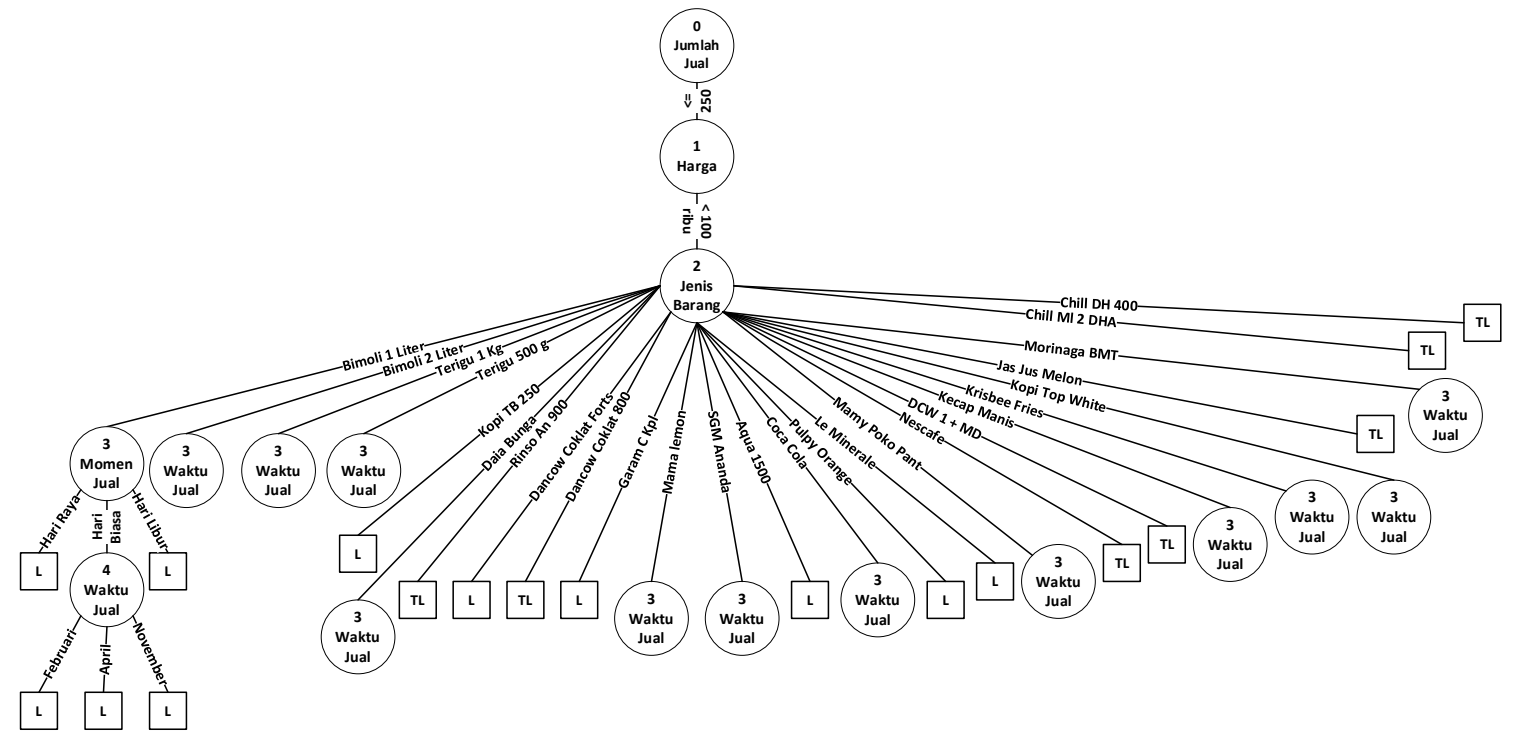

Gambar 3. Decision Tree Lanjutan 
Secara keseluruhan, pohon keputusan yang telah terbentuk akan mencapai daun (leaf). Daun adalah status penjualan barang, yaitu Laris atau Tidak Laris. Jika cabang telah mencapai daun, maka cabang tersebut akan membentuk sebuah rule.

\subsection{Rules yang Dihasilkan}

Rules yang terbentuk dari hasil training berjumlah 206 rules yang dijabarkan sebagai berikut.

1. IF Jumlah Jual (<=250) AND Harga ( $>=100$ ribu) AND Waktu Jual (Januari) THEN Tidak Laris.

2. IF Jumlah Jual ( $<=250)$ AND Harga ( $>=100$ ribu) AND Waktu Jual (Februari) THEN Laris.

3. IF Jumlah Jual $(<=250)$ AND Harga $(>=100$ ribu) AND Waktu Jual (Maret) THEN Laris.

4. IF Jumlah Jual (<=250) AND Harga ( $>=100$ ribu) AND Waktu Jual (April) THEN Laris.

5. IF Jumlah Jual $(<=250)$ AND Harga $(>=100$ ribu) AND Waktu Jual (Mei) THEN Laris.

6. IF Jumlah Jual (<=250) AND Harga ( $>=100$ ribu) AND Waktu Jual (Juni) THEN Laris.

7. IF Jumlah Jual (<=250) AND Harga ( $>=100$ ribu) AND Waktu Jual (Juli) THEN Laris.

8. IF Jumlah Jual (<=250) AND Harga ( $>=100$ ribu) AND Waktu Jual (Agustus) THEN Laris.

9. IF Jumlah Jual (<=250) AND Harga ( $>=100$ ribu) AND Waktu Jual (September) THEN Laris.

10. IF Jumlah Jual ( $<=250)$ AND Harga ( $>=100$ ribu) AND Waktu Jual (Oktober) THEN Laris.

201. IF Jumlah Jual (> 250) AND Jenis Barang (You C1000 Vit. Orange) THEN Laris.

202. IF Jumlah Jual (> 250) AND Jenis Barang (Aqua $1500 \mathrm{ml} / \mathrm{fc}$ ) THEN Laris.

203. IF Jumlah Jual (> 250) AND Jenis Barang (Bir Bintang Btl 620) THEN Laris.

204. IF Jumlah Jual (> 250) AND Jenis Barang (Coca Cola Btl 1.5 Lt) THEN Laris.

205. IF Jumlah Jual (> 250) AND Jenis Barang (Pulpy Orange 350) THEN Laris.

206. IF Jumlah Jual (> 250) AND Jenis Barang (Le Minerale Btl 600 ml) THEN Laris.

\subsection{Prediksi Data Penjualan Menggunakan Aplikasi yang Dirancang Bangun}

Proses training data yang telah dilakukan menghasilkan sebuah pohon keputusan dan rules. Rules tersebut berfungsi dalam menentukan prediksi status penjualan barang di Swalayan Dutalia. Operator akan menginput data prediksi melalui aplikasi. Data barang yang diinput tidak menyertakan atribut target, yaitu status. Sistem akan melakukan prediksi status penjualan (laris atau tidak laris) berdasarkan rules yang sudah terbentuk. Tabel 5 berikut adalah interface hasil prediksi pada aplikasi yang dibangun.

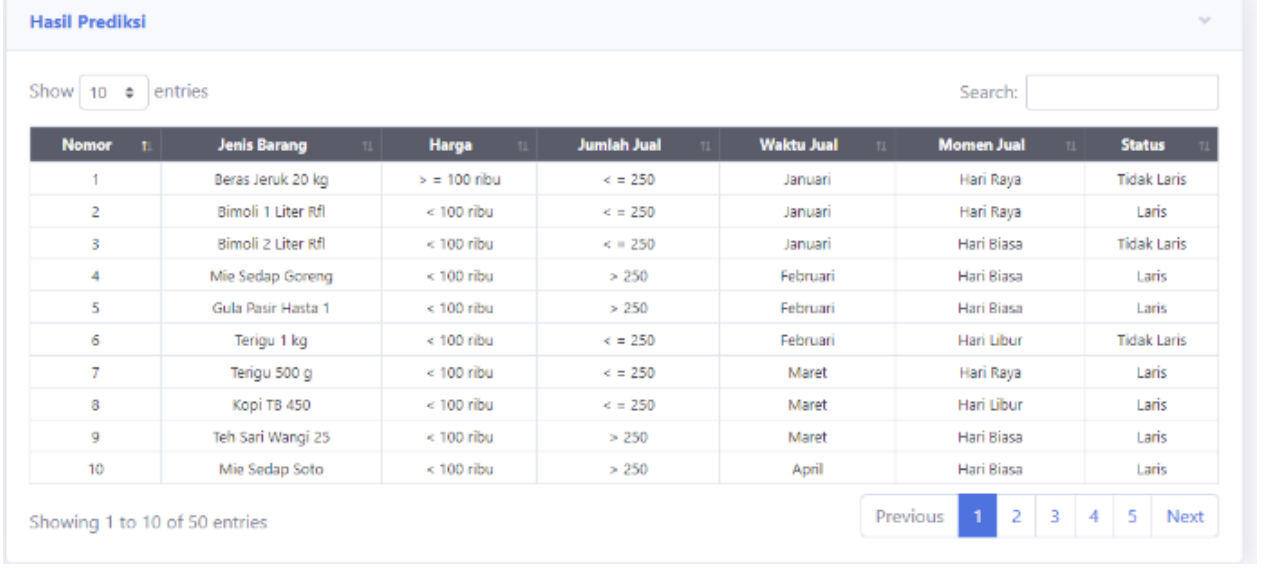

Gambar 4. Data Prediksi yang Di-input

Berdasarkan hasil training pada aplikasi dan perhitungan manual menggunakan Microsoft Office Excel, masing-masing menghasilkan result yang sama. Selain itu, decision tree dan rules yang terbentuk pun sama. Sehingga, sistem yang dirancangbangun dapat digunakan untuk melakukan proses training data mining menggunakan algoritma C4.5. Setelah diuji coba menggunakan aplikasi RapidMiner Studio Version 9.7, tingkat akurasi hasil training data dengan hasil prediksi mencapai $100 \%$. Data hasil prediksi diuji kembali sebagai data testing pada aplikasi RapidMiner Studio dan menghasilkan hasil serupa dengan dengan sistem yang dirancangbangun.

\section{ANTARMUKA SISTEM}




\subsection{Training Data}

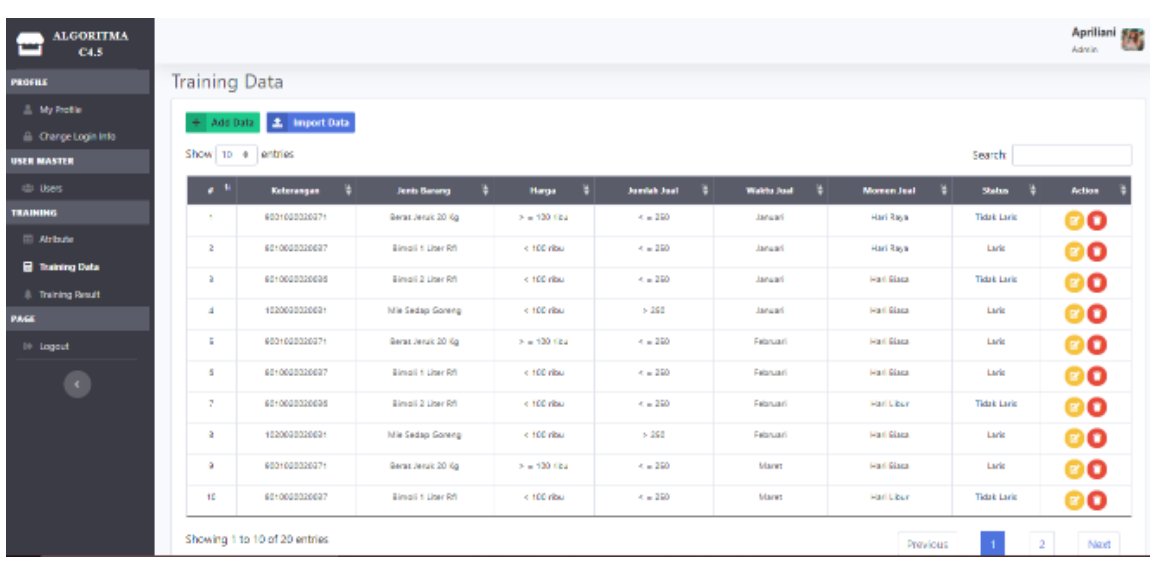

Gambar 5. Interface Data Training

Halaman training data bertujuan menampilkan tabel data training yang akan melalui proses training dengan algoritma C4.5. Data yang ditampilkan adalah atribut dan setiap nilainya.
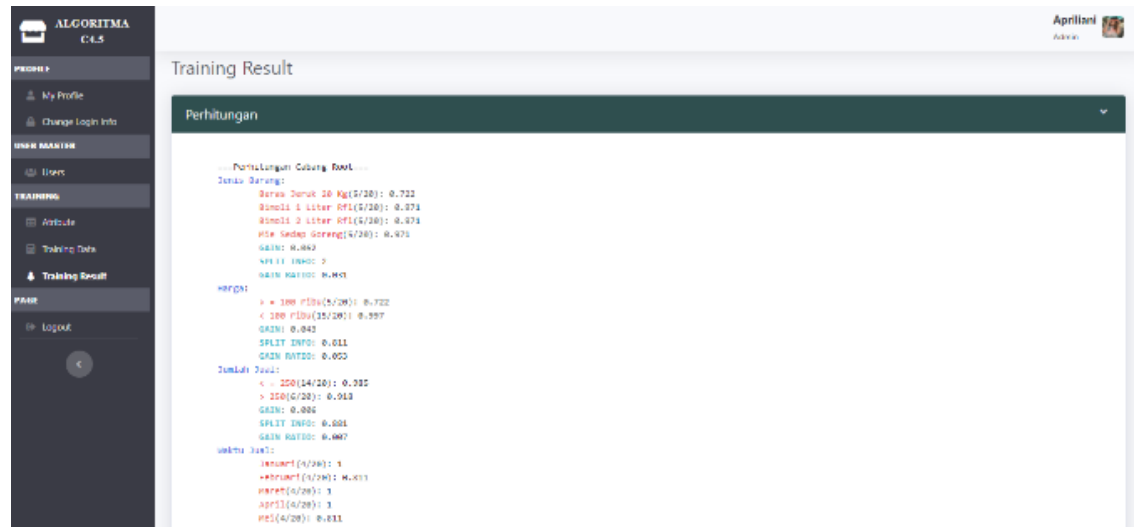

Gambar 6. Interface Hasil Perhitungan Data Training

Training result (perhitungan) akan menampilkan hasil perhitungan terhadap data training yang tersedia. Perhitungan yang ditampilkan tersebut dirinci untuk setiap atributnya.
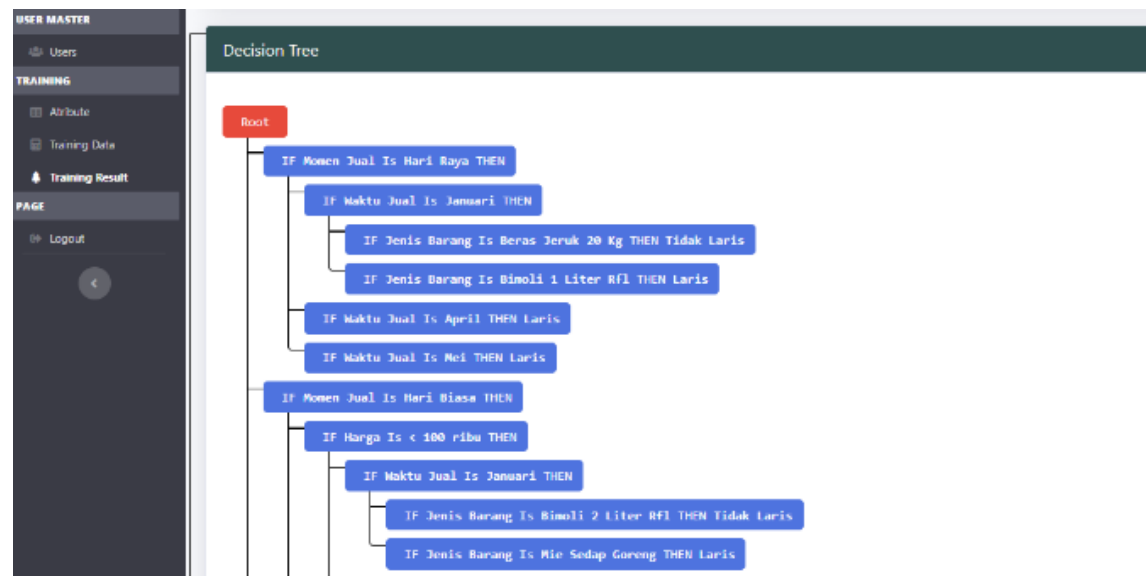

Gambar 7. Interface Decision Tree yang Dihasilkan

Training result (decision tree) menampilkan pohon keputusan yang terbentuk dari hasil perhitungan yang ada. Pohon keputusan ini yang membentuk rules terhadap data penjualan.

\subsection{Prediksi Data Penjualan}



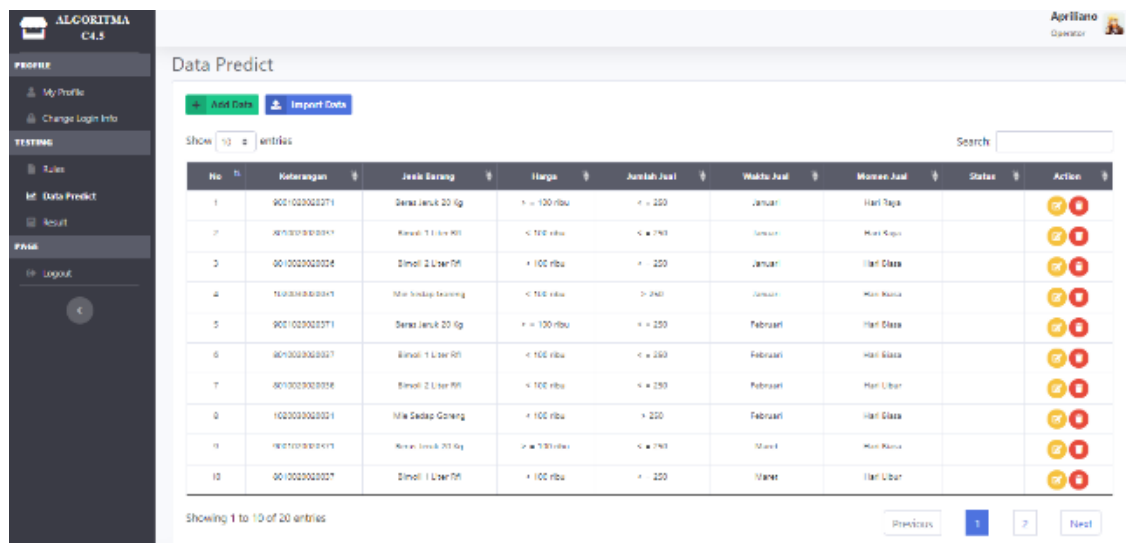

Gambar 8. Interface Data Prediction

Halaman data predict bertujuan untuk menampilkan data yang akan dilakukan prediksi. Data penjualan yang di-input tidak disertakan status penjualannya. Proses prediksi-lah yang akan menentukan status penjualan barang. Selain itu, operator dapat melakukan insert, update, dan delete data prediksi. Proses insert data predict juga dapat dilakukan dengan melakukan import file berekstensi xlxs.
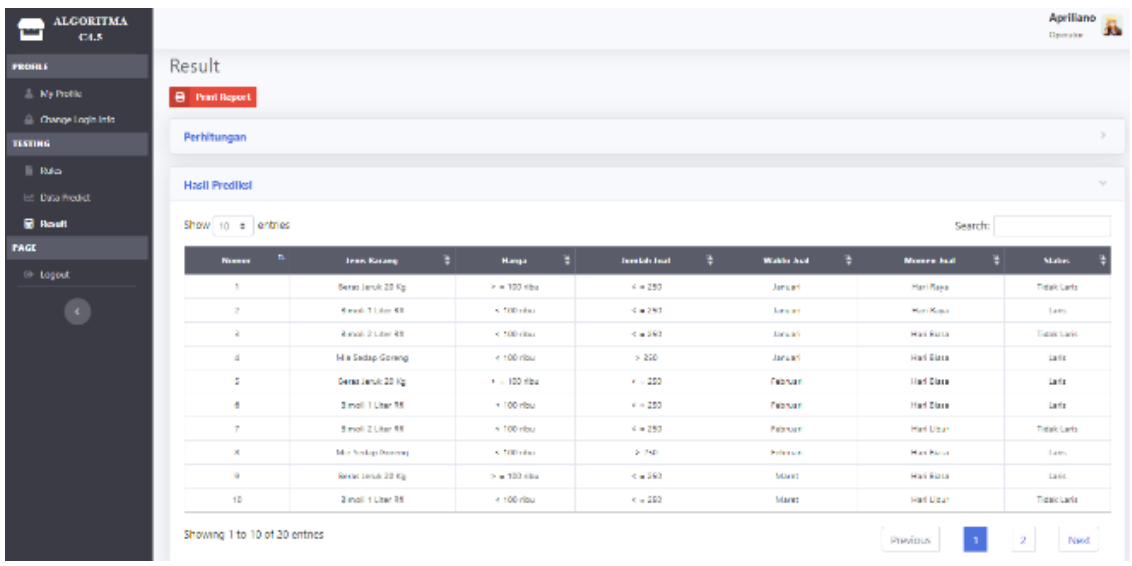

Gambar 9. Interface Tabel Hasil Prediksi

Halaman result (hasil prediksi) bertujuan untuk menampilkan tabel hasil prediksi terhadap data penjualan. Hasil prediksi ditandai dengan sudah terdapat status penjualan untuk setiap barang beserta atribut-atribut yang menentukan. Terdapat tombol print report yang bertujuan agar operator dapat melakukan pencetakan hasil prediksi yang ada.

\section{KESIMPULAN}

Berdasarkan hasil pengujian dan analisis hasil, maka dapat disimpulkan beberapa hal sebagai berikut.

1. Sistem yang dirancang bangun bermanfaat bagi pihak Swalayan Dutalia melakukan klasifikasi berupa training data penjualan di masa lampau menggunakan algoritma $\mathrm{C} 4.5$ guna menghasilkan rules yang dapat digunakan untuk melakukan prediksi data penjualan masa depan. Sehingga, pihak swalayan dapat menentukan stok minimum yang harus disediakan.

2. Sistem yang dirancangbangun dapat melakukan create, read, update, dan delete (CRUD) data atribut, nilai atribut, data training, dan data prediksi. Selain itu, user juga dapat melihat hasil prediksi dan hasil training berupa perhitungan dan decision tree.

3. Sistem yang dirancangbangun dapat melakukan input data training dan data prediksi menggunakan fitur import excel.

4. Sistem yang dirancangbangun dapat mencetak laporan hasil prediksi berupa tabel data hasil prediksi.

5. Sistem klasifikasi menggunakan algoritma $\mathrm{C} 4.5$ yang dirancangbangun memiliki tingkat akurasi $100 \%$ setelah 50 data hasil prediksi diuji coba sebagai data testing pada aplikasi RapidMiner Studio 
Version 9.7. Decision tree yang dihasilkan pada perhitungan manual, sistem yang dirancangbangun, dan aplikasi RapidMiner pun sama.

\section{DAFTAR PUSTAKA}

[1]. Anharku. (2016). Flowchart. Retrieved from Analisis dan Perancangan Sistem website: http://ilmukomputer.org

[2]. Eska, J. (2016). PENERAPAN DATA MINING UNTUK PREDIKSI PENJUALAN WALLPAPER MENGGUNAKAN ALGORITMA C4.5. JURTEKSI (Jurnal Teknologi Dan Sistem Informasi), 2(2), 9-13.

[3]. Harahap, F. (2015). Penerapan Data Mining dalam Memprediksi Pembelian cat. Konferensi Nasional Sistem \& Informatika 2015 STMIK, 1(1), 856-862.

[4]. Kamagi, D. H., \& Hansun, S. (2014). Implementasi Data Mining dengan Algoritma C4 . 5 untuk Memprediksi Tingkat Kelulusan Mahasiswa. ULTIMATICS, VI(1), 15-20.

[5]. Mardi, Y. (2016). Data Mining: Klasifikasi Menggunakan Algoritma C4.5. Jurnal Edik Informatika, 2(2), 213-219.

[6]. Nurmalina, R. (2017). Perencanaan dan Pengembangan Aplikasi Absensi Mahasiswa Menggunakan Smart Card Guna Pengembangan Kampus Cerdas ( Studi Kasus Politeknik Negeri Tanah Laut ). Jurnal Integrasi, 9(1), 84-91.

[7]. Oracle. (2019). MySQL. Retrieved from Wikipedia Ensiklopedia Bebas website: https://id.wikipedia.org/wiki/MySQL

[8]. Pritalia, G. L. (2018). Penerapan Algoritma C4 . 5 untuk Penentuan Ketersediaan Barang Ecommerce. Indonesian Journal of Information Systems (IJIS) Vol., 1(1), 47-56.

[9]. Rosela, Y. (2019). IMPLEMENTASI KLASIFIKASI DECISION TREE MENGANALISA STATUS PENJUALAN BARANG MENGGUNAKAN C4 . 5 ( Studi Kasus : Pt . Matahari Department Store Medan Mall ). Jurnal Pelita Informatika, 18(1), 143-150.

[10]. Suyanto, D. (2017). Data Mining Untuk Klasifikasi Dan Klasterisasi Data (1st ed.; I. Bandung, Ed.). Bandung: Informatika Bandung.

[11]. Tristianto, C. (2018). PENGGUNAAN METODE WATERFALL UNTUK PENGEMBANGAN SISTEM MONITORING DAN EVALUASI PEMBANGUNAN PEDESAAN. Jurnal Teknologi Informasi ESIT, XII(01), 8-22.

[12]. Turnip, M., \& Wijaya, C. (2016). PENERAPAN ALGORITMA C4.5 UNTUK PENENTUAN TINGKAT KONSUMSI KONSUMEN PADA MEDAN SOLUSINDO. Jurnal Senopati (Seminar Nasional Pascasarjana Teknik Informatika) Vol, 1(1), 34-42. 